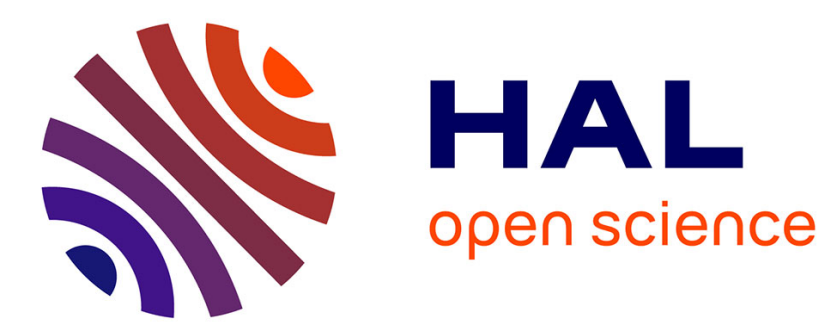

\title{
Direct and Rapid Profiling of Biophenols in Olive Pomace by UHPLC-DAD-MS
}

Aurélia Malapert, Emmanuelle Reboul, Michele Loonis, Olivier Dangles, Valérie Tomao

\section{- To cite this version:}

Aurélia Malapert, Emmanuelle Reboul, Michele Loonis, Olivier Dangles, Valérie Tomao. Direct and Rapid Profiling of Biophenols in Olive Pomace by UHPLC-DAD-MS. Food Analytical Methods, 2017, 11 (4), pp.1-10. 10.1007/s12161-017-1064-2 . hal-01709338

\section{HAL Id: hal-01709338 \\ https://hal.science/hal-01709338}

Submitted on 25 May 2018

HAL is a multi-disciplinary open access archive for the deposit and dissemination of scientific research documents, whether they are published or not. The documents may come from teaching and research institutions in France or abroad, or from public or private research centers.
L'archive ouverte pluridisciplinaire HAL, est destinée au dépôt et à la diffusion de documents scientifiques de niveau recherche, publiés ou non, émanant des établissements d'enseignement et de recherche français ou étrangers, des laboratoires publics ou privés. 


\title{
Direct and Rapid Profiling of Biophenols in Olive Pomace by UHPLC-DAD-MS
}

\author{
Aurélia Malapert ${ }^{1} \cdot$ Emmanuelle Reboul $^{2} \cdot$ Michèle Loonis $^{1} \cdot$ Olivier Dangles $^{1}$. \\ Valérie Tomao ${ }^{1}$
}

\begin{abstract}
Olive mill by-products are effluents generated during olive oil production process. The two-phase centrifugation system produces a semi-solid olive pomace called "alperujo." This by-product is a combination of liquid and solid wastes derived from the three-phase manufacturing process. A direct and fast analytical method by ultra-high-pressure liquid chromatography-DAD coupled with ESI/MS-MS has been developed for the profiling of phenolic compounds. Thirtyfive metabolites belonging to phenyl alcohols, secoiridoids, flavonoids, and iridoids were identified as the main constituents of alperujo in $12 \mathrm{~min}$, including $p$-coumaroyl aldarate and a verbascoside derivative found for the first time in alperujo and a new ligstroside derivative. Six quantitatively significant components were determined at concentrations ranging from $17.7 \mathrm{mg} / \mathrm{L}$ for $p$-coumaric acid to $370.7 \mathrm{mg} / \mathrm{L}$ for hydroxytyrosol. Our data confirm that alperujo is an interesting source of phenolic compounds that could be extracted for use as nutraceuticals.
\end{abstract}

Keywords Alperujo - Two-phase olive pomace · Olive phenolic compounds - Biophenols - Fast analysis - UHPLC/ MS

Valérie Tomao

valerie.tomao@univ-avignon.fr

1 INRA, UMR408 SQPOV, University of Avignon, 84000 Avignon, France

2 UMR 1062 INSERM/1260 INRA, Aix-Marseille University, Marseille, France

\section{Introduction}

The Mediterranean landscape is since ancient time associated with the culture of olive trees. Today, it is estimated that nearly $98 \%$ of the global olive production originates in the Mediterranean basin, among which $73 \%$ in Southern Europe with Spain, Italy, and Greece as the main producers (Conseil Oléicole Intemational 2013; Ollivier et al. 2014).

The ever-growing olive oil production is correlated with the accumulation of olive mill wastes, and several types of by-products may be generated depending on the process used. Three-phase mills, using large volumes of water to improve the feasibility and the efficiency of oil extraction (Kapellakis et al. 2008; Niaounakis and Halvadakis 2006), generate two by-products: the olive mill wastewater and a solid waste known as olive pomace composed of olive pulp, skins, and stones. The modern two-phase processing technique, requiring no addition of water during oil extraction, produces the wet olive pomace consisting of vegetation water and solid olive particles (Dermeche et al. 2013). This new process is associated with a lower volume of by-products, thus minimizing the associated environmental impact. However, these byproducts are still a major source of pollutants from oil mills, largely because of its phenolic compounds labeled as phytotoxic compounds (Alburquerque et al. 2006). On the other hand, alperujo provides a rich source of phenolic compounds (e.g., oleuropein, verbascoside, apigenin-7-glucoside, luteolin-7-glucoside) known to possess important healthpromoting properties by different mechanisms (antioxidant activity, modulation of a variety of cell signaling pathways) to protect against degenerative diseases (Giordano et al. 2015; Visioli and Bemardini 2011; Obied et al. 2007a). 
The main methods proposed for determination of the phenolic compounds from alperujo include advanced chromatographic techniques coupled to mass spectrometry. Cardoso et al. investigated olive pulp and pomace by-products by electrospray ionization mass spectrometry, allowing the identification of common phenolic compounds and for the first time two oleoside derivatives (Cardoso et al. 2005). Obied et al. achieved highresolution separation of 52 compounds from alperujo extracts in less than $60 \mathrm{~min}$ by chemical screening using reversed phase HPLC-diode array detection (RPLC-DAD) and RPLCelectrospray ionization mass spectrometry (RPLC-ESI-MS) (Obied et al. 2007b). Rubio-Senent et al. identified 26 phenolic compounds in $48 \mathrm{~min}$ by HPLC/MS after application of a process based on the hydrothermal treatment of alperujo and subsequent extraction by ethyl acetate (Rubio-Senent et al. 2012). Using the same pretreatment of alperujo, Rubio-Senent et al. identified also a polymeric phenolic fraction at the end of the separation (Rubio-Senent et al. 2013) and were also able to isolate and identify some minor secoiridoids, such as oleuropein derivatives (Rubio-Senent et al. 2015). Besides HPLC-MS, capillary electrophoresis (CE) was also used for alperujo analysis. For instance, after ultrasound-assisted extraction, 20 biophenols were separated and identified in $11 \mathrm{~min}$ by CE-DAD (PriegoCapote et al. 2004).

The present study reports a rapid, reliable and efficient analytical method to extract and characterize the wet olive pomace by ultra-high performance liquid chromatography (UHPLC)-DAD coupled with ESI-MS/MS without any preliminary extraction procedure to preserve both the maximal content and integrity of its phenolic compounds.

\section{Materials and Methods}

\section{Chemicals}

Alperujo was collected in October 2014 from Aglandau olives processed at a two-phase olive oil mill (Moulin Castelas, Bauxde-Provence, France). Samples were immediately frozen and stored at $-20^{\circ} \mathrm{C}$ before chemical analyses. All solvents were of HPLC grade from VWR International (Darmstadt, Germany). p-Coumaric acid, caffeic acid, chlorogenic acid, gallic acid, 3,4- dihydroxybenzoic acid, hydroxytyrosol, rutin, taxifolin, and vanillin were supplied by Sigma-Aldrich (Deisenhofer, Germany). Quinic acid, (E)-cinnamic acid, ferulic acid, homovanillic acid, syringic acid, vanillic acid, apigenin, luteolin, luteolin-7- $O$-glucoside, catechol, oleuropein, tyrosol, and verbascoside were obtained from Extrasynthèse (Genay, France).

\section{Two-Phase Olive Pomace Preparation}

Two-phase olive pomace was pressed (Tompress, France) and filtered through celite on a Buchner funnel, then through a 0.2- $\mu \mathrm{m}$ PTFE filter (Alltech Associates, Deerfield, IL) prior to UHPLC analyses.

\section{Two-Phase Olive Pomace Characterization in Terms of Phenolic Compounds}

\section{Chromatographic and Mass Spectrometric Conditions}

UHPLC-DAD-MS analyses were performed using an Acquity UPLC® system (Waters, Milford, MA, USA) linked to both a diode array detector (DAD 200-800 nm, Waters, Milford, MA, USA) and a Bruker Daltonics HCT Ultra Ion Trap Mass Spectrometer equipped with an Electron Spray Ionization (ESI) source operating in negative ion mode. The separation was performed on an Acquity C18 BEH column (1.7 $\mu \mathrm{m}, 2.1 \times 50 \mathrm{~mm}$ ). The solvents were (A) water/formic acid (99.5/0.5) and (B) acetonitrile. The gradient was linear, and the proportions of solvent B used were as follows: 0 $10 \mathrm{~min} 1-20 \%, 10-12 \mathrm{~min} 20-30 \%$, and $12-14 \mathrm{~min} 30-$ $100 \%$. The injection volume was $1 \mu \mathrm{L}$, and the column temperature was kept at $35^{\circ} \mathrm{C}$. Along the three steps of the gradient, the flow rate was $0.30,0.35$, and $0.40 \mathrm{~mL} / \mathrm{min}$. The spectroscopic detection was performed in the range 200$600 \mathrm{~nm}$ with a resolution of $1.2 \mathrm{~nm}$. The concentrations of the main phenolic compounds were estimated from calibration curves (peak area vs. concentration) constructed with hydroxytyrosol, tyrosol, caffeic acid, and p-coumaric acid. The quantification of the glucoside forms of hydroxytyrosol were undertaken as millimoles of hydroxytyrosol equivalent per liter. Limits of detection (LOD) and quantification (LOQ) of these four standards were determined by the signal-to-noise

Table 1 Calibration curves, limits of detection (LOD), and quantification (LOQ) of standard biophenols

\begin{tabular}{lllllll}
\hline Standard & $t_{\mathrm{R}}(\mathrm{min})$ & $\lambda_{\max }(\mathrm{nm})$ & Calibration line & $R^{2}$ & LOD $(\mathrm{ng} / \mu \mathrm{L})$ & LOQ $(\mathrm{ng} / \mu \mathrm{L})$ \\
\hline Hydroxytyrosol & 2.28 & 227,280 & $y=2.093 \times 10^{6} x-1703.36$ & 0.9998 & 0.54 & 1.79 \\
Tyrosol & 3.23 & 227,276 & $y=1.907 \times 10^{6} x-2540.69$ & 0.9996 & 2.35 & 7.84 \\
Caffeic acid & 4.11 & $239,295 \mathrm{sh}, 324$ & $y=2.285 \times 10^{6} x-2128.28$ & 0.9993 & 0.23 & 0.78 \\
$p$-Coumaric acid & 5.50 & 224,309 & $y=6.891 \times 10^{7} x+2189.48$ & 0.9999 & 0.24 & 0.80 \\
\hline
\end{tabular}

$s h$ : shoulder, $y$ : peak area, $x$ : mass in milligrams 
Table 2 Retention times $\left(t_{\mathrm{R}}\right)$ and UV-visible characteristics of standard biophenols

\begin{tabular}{llll}
\hline Standard & $t_{\mathrm{R}}(\mathrm{min})$ & $\lambda_{\max }(\mathrm{nm})$ & \\
\cline { 4 - 4 } & & Standard & Sample \\
\hline Gallic acid & 1.14 & 229,271 & nd \\
3,4-Dihydroxybenzoic acid & 2.03 & 258,294 & nd \\
Hydroxytyrosol & 2.28 & 227,280 & 227,280 \\
Catechol & 2.60 & 276 & nd \\
Tyrosol & 3.23 & 227,276 & 224,276 \\
Chlorogenic acid & 3.91 & $242,301,327$ & $244,296,327$ \\
Vanillic acid & 3.95 & 261,293 & nd \\
Caffeic acid & 4.11 & $239,295 \mathrm{sh}, 324$ & $234,295 \mathrm{sh}, 325$ \\
Syringic acid & 4.49 & 227,275 & nd \\
Homovanillic acid & 4.59 & 235,280 & nd \\
Vanillin & 5.04 & $242,280,309$ & nd \\
$p$-Coumaric acid & 5.50 & 224,309 & 227,309 \\
Ferulic acid & 6.41 & $238,297 \mathrm{sh}, 324$ & $237,296 \mathrm{sh}, 322$ \\
Taxifolin & 6.88 & 289 & nd \\
Rutin & 7.35 & 256,354 & nd \\
Luteolin-7-O-glucoside & 7.76 & 255,349 & nd \\
Verbascoside & 8.27 & $235,290 \mathrm{sh}, 331$ & $235,291 \mathrm{sh}, 330$ \\
Oleuropein & 10.38 & 235,281 & nd \\
(E)-Cinnamic acid & 10.96 & 224,278 & nd \\
Luteolin & 11.13 & 253,348 & nd \\
\hline
\end{tabular}

$s h$ : shoulder, $n d$ : not detected

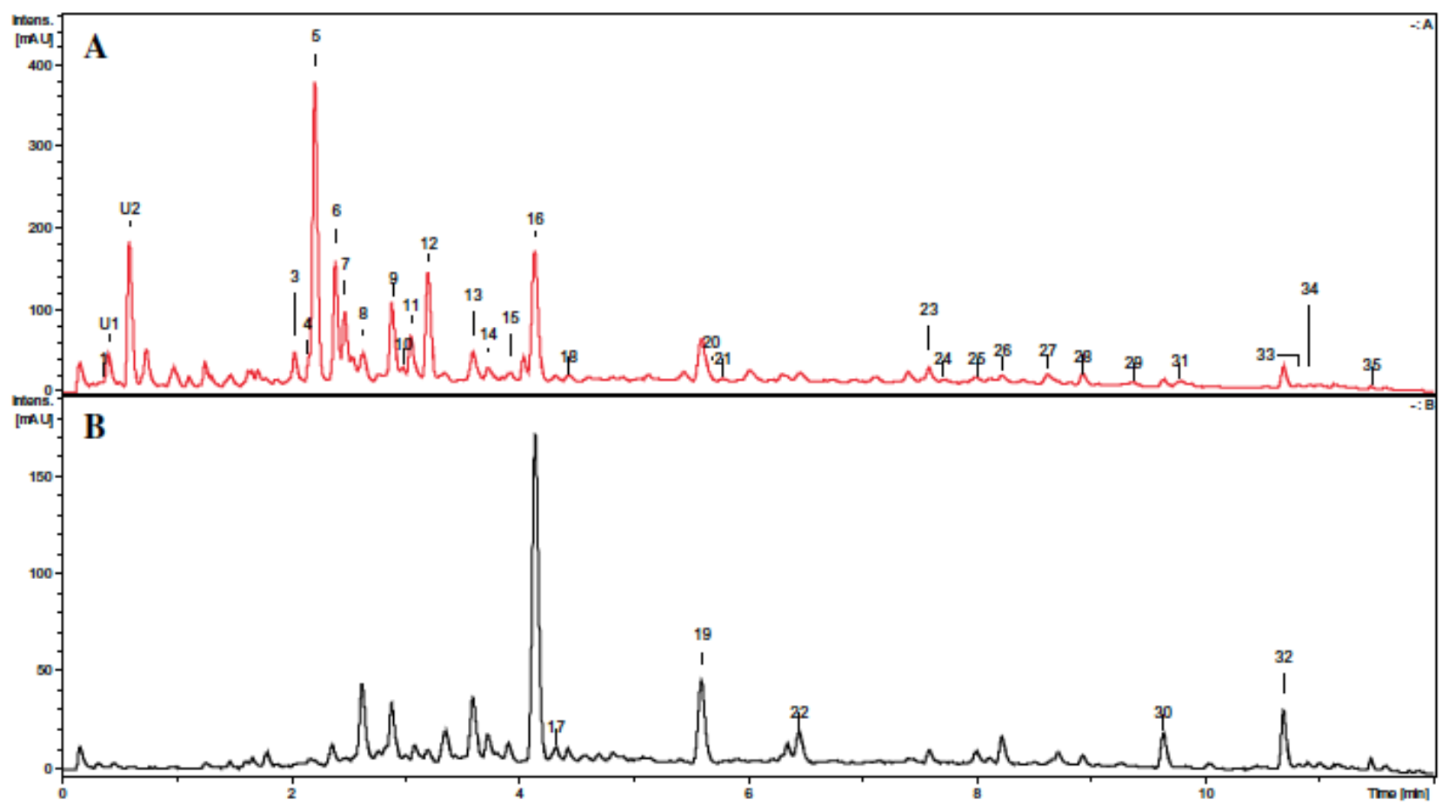

Fig 1 UHPLC chromatograms of alperujo juice with detection at $280 \mathrm{~nm}$ (a) and $330 \mathrm{~nm}$ (b) 
Table 3 Retention times, UV-visible, and MS data of alperujo phenolic compounds and other metabolites

\begin{tabular}{|c|c|c|c|c|c|c|}
\hline No. & $t_{\mathrm{R}}(\min )$ & Compound & $\lambda_{\max }(\mathrm{nm})$ & $m / z$ & Fragments & References \\
\hline 1 & 0.46 & Quinic acid & - & 191 & $173,127,111$ & D'Antuono et al. (2014) \\
\hline $\mathrm{U}_{1}$ & 0.52 & Unknown 1 & 232,267 & 191 & $173,127,111$ & \\
\hline $\mathrm{U}_{2}$ & 0.77 & Unknown 2 & 227,279 & 191 & $173,127,111$ & \\
\hline 2 & 1.75 & Verbascoside - Rha & $234,282,308$ & 477 & $459,367,161$ & Cardinali et al. (2012) \\
\hline 3 & 2.12 & Loganic acid glucoside & 232,283 & 537 & $375,331,179$ & Peralbo-Molina et al. (2012) \\
\hline 4 & 2.25 & Vanillic acid hexoside & 254,293 & 329 & $167,151,123,108$ & \\
\hline 5 & 2.31 & Hydroxytyrosol (HT) & 227,280 & 153 & & $\begin{array}{l}\text { Leoui foudi et al. (2014) } \\
\text { Rubio-Senent et al. (2013) }\end{array}$ \\
\hline 6 & 2.35 & Hydroxytyrosol glucoside 1 & 231,277 & 315 & 153,123 & $\begin{array}{l}\text { D'Antuono et al. (2014) } \\
\text { Obied et al. (2007b) }\end{array}$ \\
\hline 7 & 2.46 & Hydroxytyrosol glucoside 2 & 231,279 & 315 & 153,123 & $\begin{array}{l}\text { D'Antuono et al. (2014) } \\
\text { Obied et al. (2007b) }\end{array}$ \\
\hline 8 & 2.55 & p-Coumaroyl aldarate & 313 & 355 & $337,209,191,147,129$ & $\begin{array}{l}\text { First report in olive } \\
\text { Steingass et al. (2015) }\end{array}$ \\
\hline 9 & 2.72 & $\begin{array}{l}\text { 1-B-Glucosyl-acyclo- } \\
\text { dihydroelenolic acid }\end{array}$ & 236,294 & 407 & $389,375,357,313,161$ & $\begin{array}{l}\text { Cardoso et al. (2005) } \\
\text { D'Antuono et al. (2014) } \\
\text { Rubio-Senent et al. (2015) }\end{array}$ \\
\hline 10 & 3.05 & $\begin{array}{l}\text { Hydroxylated DCMEA } \\
\text { derivative }\end{array}$ & 236 & 199 & $181,155,111$ & $\begin{array}{l}\text { Kanakis et al. (2013) } \\
\text { Lozano-Sánchez et al. (2014) }\end{array}$ \\
\hline 11 & 3.15 & Verbascoside - CA & 237,281 & 461 & $315,297,161,135$ & $\begin{array}{l}\text { First report in olive } \\
\text { Sanz et al. (2012) }\end{array}$ \\
\hline 12 & 3.29 & Tyrosol & 227,276 & 137 & 119 & $\begin{array}{l}\text { Kanakis et al. (2013) } \\
\text { Peralbo-Molina et al. (2012) }\end{array}$ \\
\hline 13 & 3.71 & Fenuloyl-hexoside & 286,320 & 401 & 355,193 & \\
\hline 14 & 3.73 & Caffeoyl-hexoside & $239,286 \mathrm{sh}, 318$ & 341 & 179,135 & \\
\hline 15 & 4.02 & Chlorogenic acid & $244,296,327$ & 353 & $247,163,135,109$ & Rubio-Senent et al. (2012) \\
\hline 16 & 4.24 & Caffeic acid (CA) & $238,295 \mathrm{sh}, 325$ & 179 & 163,135 & $\begin{array}{l}\text { Obied et al. (2007b) } \\
\text { Suárez et al. (2008) }\end{array}$ \\
\hline 17 & 4.43 & p-Coumaroyl-hexoside & 240,325 & 325 & $265,163,119$ & \\
\hline 18 & 4.55 & Oleoside & 236 & 389 & $345,209,165$ & $\begin{array}{l}\text { Bouaziz et al. (2010) } \\
\text { D'Antuono et al. (2014) }\end{array}$ \\
\hline 19 & 5.69 & p-Coumaric acid & 227,309 & 163 & 119 & $\begin{array}{l}\text { Leoui foudi et al. (2014) } \\
\text { Rubio-Senent et al. (2012) }\end{array}$ \\
\hline 20 & 5.73 & Oleoside deoxyriboside & 239,278 & 505 & $389,345,121$ & Peralbo-Molina et al. (2012) \\
\hline 21 & 5.77 & Oleuropein aglycone & 245,282 & 377 & 197,153 & $\begin{array}{l}\text { Cardoso et al. (2005) } \\
\text { D'Antuono et al. (2014) } \\
\text { Rubio-Senent et al. (2013) }\end{array}$ \\
\hline 22 & 6.60 & Fenulic acid & $237,296 \mathrm{sh}, 322$ & 193 & 149 & $\begin{array}{l}\text { Obied et al. (2007b) } \\
\text { Peralbo-Molina et al. (2012) }\end{array}$ \\
\hline 23 & 7.75 & Luteolin- $O$-rutinoside & 246,346 & 593 & 285 & $\begin{array}{l}\text { Leoui foudi et al (2014) } \\
\text { Rubio-Senent et al. (2012) }\end{array}$ \\
\hline 24 & 7.87 & Luteolin- $O$-rutinoside & 244,346 & 593 & 285 & $\begin{array}{l}\text { Leoui foudi et al (2014) } \\
\text { Rubio-Senent et al. (2012) }\end{array}$ \\
\hline 25 & 8.18 & Elenolic acid & 244 & 241 & $209,165,139,127,121,101$ & $\begin{array}{l}\text { Kanakis et al. (2013) } \\
\text { Suárez et al. (2009) }\end{array}$ \\
\hline 26 & 8.39 & Verbascoside & $235,291 \mathrm{sh}, 330$ & 623 & $461,477,315$ & $\begin{array}{l}\text { Rubio-Senent et al. (2012) } \\
\text { Suárez et al (2009) }\end{array}$ \\
\hline 27 & 8.82 & Tetrahydro-oleuropein & 246,279 & 543 & 525,513 & Kanakis et al. (2013) \\
\hline 28 & 9.17 & Nūzhenide & $246,282,334$ & 685 & $523,453,421,299$ & Silva et al. $(2006,2010)$ \\
\hline 29 & 9.41 & Oleuropein glucoside & 250,279 & 701 & $539,377,307,275$ & Cardoso et al. (2005) \\
\hline 30 & 9.79 & Caffeoyl-6'-secologanoside & $225,290,327$ & 551 & $507,389,385,341,281,251,221,179,161$ & Obied et al (2007b) \\
\hline
\end{tabular}


Table 3 (continued)

\begin{tabular}{|c|c|c|c|c|c|c|}
\hline No. & $t_{\mathrm{R}}(\min )$ & Compound & $\lambda_{\max }(\mathrm{nm})$ & $m / z$ & Fragments & References \\
\hline & & & & & & Rubio-Senent et al. (2012) \\
\hline 31 & 9.91 & $\begin{array}{l}\text { 10-Hydroxy-DCMO } \\
\text { aglycone }\end{array}$ & 243,281 & 335 & $199,155,111$ & $\begin{array}{l}\text { Lozano-Sánchez et al. (2014) } \\
\text { Suárez et al. (2008) }\end{array}$ \\
\hline 32 & 10.86 & Comselogoside & 240,313 & 535 & $491,389,345,307,265,163$ & $\begin{array}{l}\text { Obied et al. (2007b) } \\
\text { Rubio-Senent et al. (2013) }\end{array}$ \\
\hline 33 & 11.02 & Oleuroside & 244,282 & 539 & $469,437,377,307,275$ & Kanakis et al. (2013) \\
\hline 34 & 11.09 & Ligstroside derivative & 246,277 & 655 & $517,361,291,259$ & New compound \\
\hline 35 & 11.69 & Ligstroside isomer & 248,282 & 523 & $453,421,299$ & Cardoso et al. (2011) \\
\hline
\end{tabular}

$s h$ shoulder, DCMEA decarboxymethyl elenolic acid, $D C M O$ decarboxymethyl oleuropein

$(\mathrm{S} / \mathrm{N})$ evaluations. Low concentrations were injected to attempt a S/N equal to 3 and 10 for LOD and LOQ, respectively (Table 1). All analyses were run in triplicate.

ESI mass spectra were obtained at ionization energies of 50 and $100 \mathrm{eV}$ in negative mode, the capillary voltage was $2 \mathrm{kV}$, the source temperature was $365^{\circ} \mathrm{C}$, the drying gas was introduced at a flow rate of $10 \mathrm{~L} / \mathrm{min}$, and the skimmer voltage was $40 \mathrm{~V}$. Scans were performed in the $\mathrm{m} / \mathrm{z}$ range $100-800$. Identification of phenolic compounds in samples was performed after standard injection from analysis of retention times, UV-visible spectra, MS molecular peaks and fragments, and comparison with literature data. Tentative identifications of new biophenols were deduced from MS fragmentation.

\section{Results and Discussion}

\section{Phenolic Profiles in Alperujo Juice}

In our UHPLC/MS method, LC and mass parameters for native alperujo juice have been optimized, such as injection volume of samples, flow rate of mobile phase, peak resolution, mass collision energy, and fragmentation voltage. The optimized
Fig. 2 Chemical structures of common secoiridoids in alperujo<smiles>CC=C1C(OC(C)(C)C)OC=C(C(=O)O)[C@@H]1CC(=O)O</smiles><smiles>CC(=O)C1=COC(C)C(C=O)[C@H]1CC(=O)O</smiles>

Elenolic acid

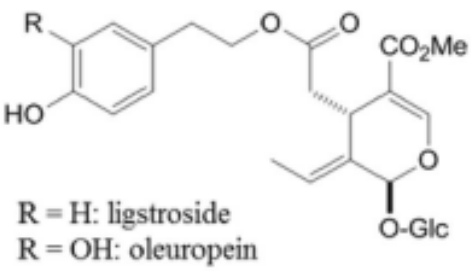<smiles>C=C[C@@H]1[C@H](CC(=O)OCCc2ccc(O)c(O)c2)OC=C(C(C)=O)[C@@H]1OC(C)C</smiles>

Oleuroside<smiles>C/C=C1/C(CC(=O)OCC2OC(OCCc3ccc(O)cc3)C(O)C(O)C(O)C2O)C(C(C)=O)=CO[C@H]1OC(C)C</smiles>

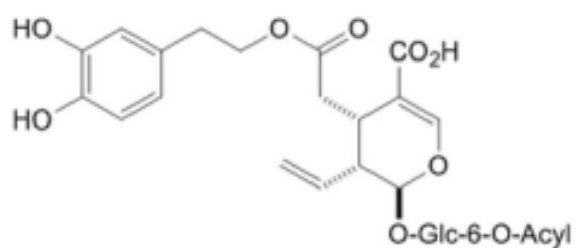



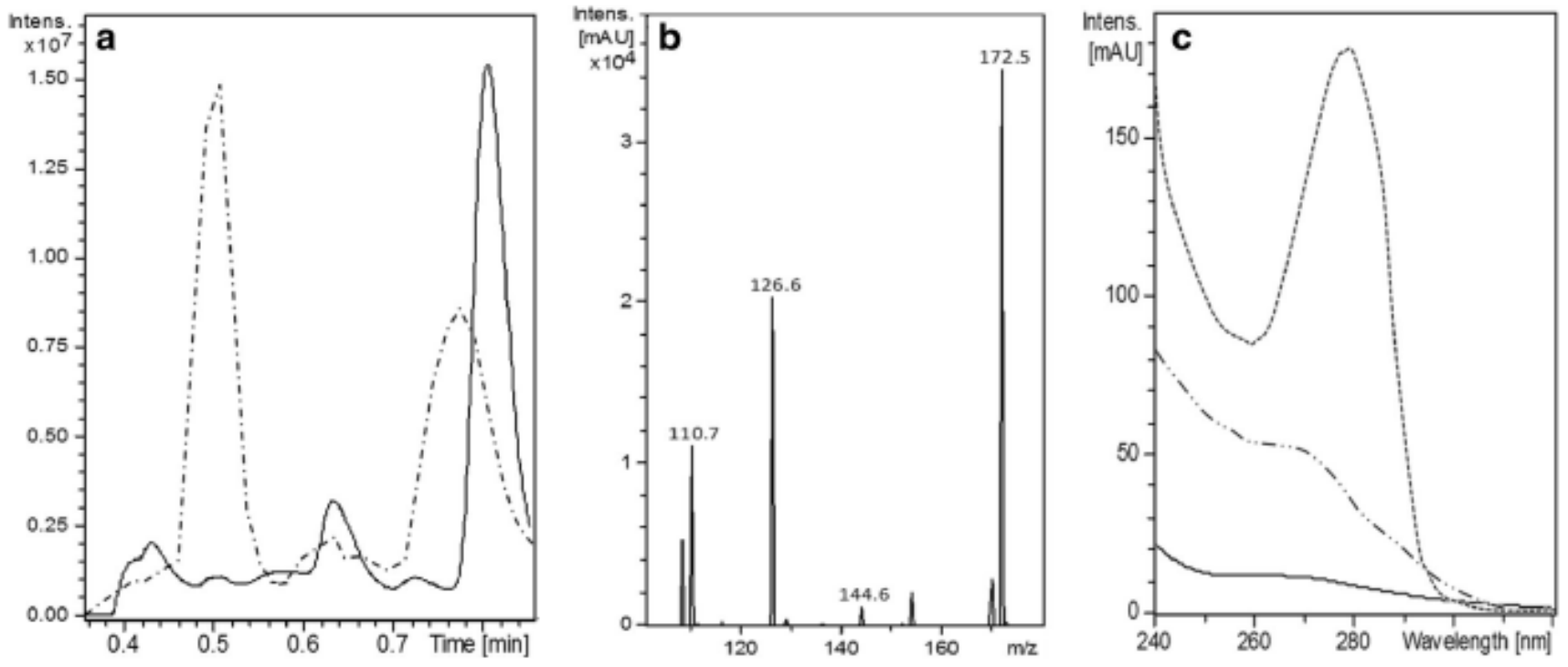

Fig. 3 Extracted ion chromatogram (EIC) at $m / z=191$ and chromatogram at $280 \mathrm{~nm}$ (a), mass spectrum of quinic acid (b), and UV spectra of compounds at $m / z=191$ (c). a Continuous line:

conditions showed appropriate fragmentation with the detection of the parent ion $[\mathrm{M}-\mathrm{H}]$ for all compounds over the $12 \mathrm{~min}$ runtime. The analysis of injected standards is summarized in Table 2 .

Figure 1 shows a typical chromatographic analysis with detection at $280 \mathrm{~nm}$ (total phenols) and $330 \mathrm{~nm}$ (hydroxycinnamic acids, flavones, and flavonols). Table 3 summarizes the phenolic compounds identified in the alperujo juice and their UHPLC-DAD-MS characteristics (peak numbering according to elution order).

The large number of peaks confirmed the complexity of alperujo juice in terms of its phenolic composition. Figure 2 shows some chemical structures of common secoiridoids identified in alperujo.

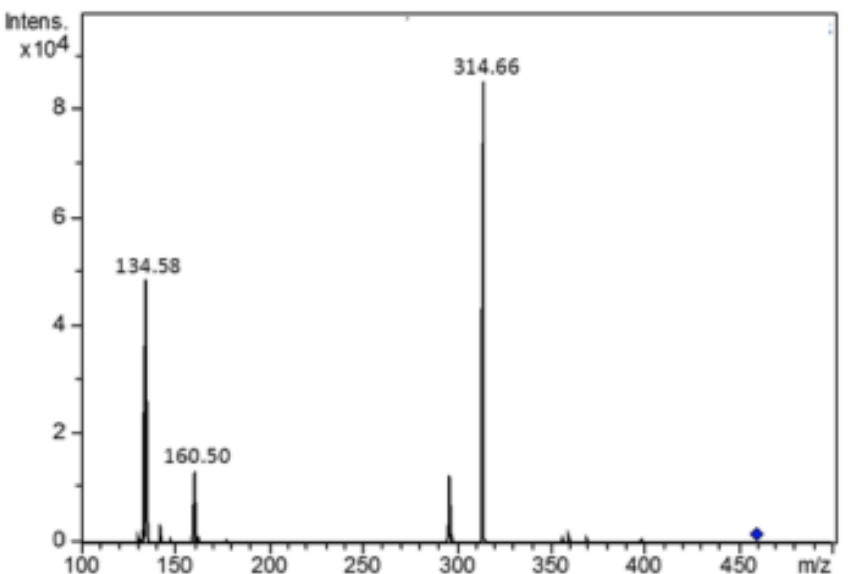

\section{Quinic Acid and Isomers at $m / z=191$}

Compound 1 assigned to quinic acid was not detected by $\mathrm{DAD}$ at $280 \mathrm{~nm}$, but its identity was confirmed by injection of the authentic standard. Two peaks at $m / z=191$ and retention times of 0.52 and $0.77 \mathrm{~min}$ show the same parent ion and molecular fragments as quinic acid. However, they are detectable by DAD and slightly differ by their UV spectra (Fig. 3). These data did not permit their identification.

\section{Verbascoside and Derivatives}

Peak 2 displays a molecular ion at $\mathrm{m} / \mathrm{z}=477$ consistent with hydrolysis of the rhamnose residue from verbascoside

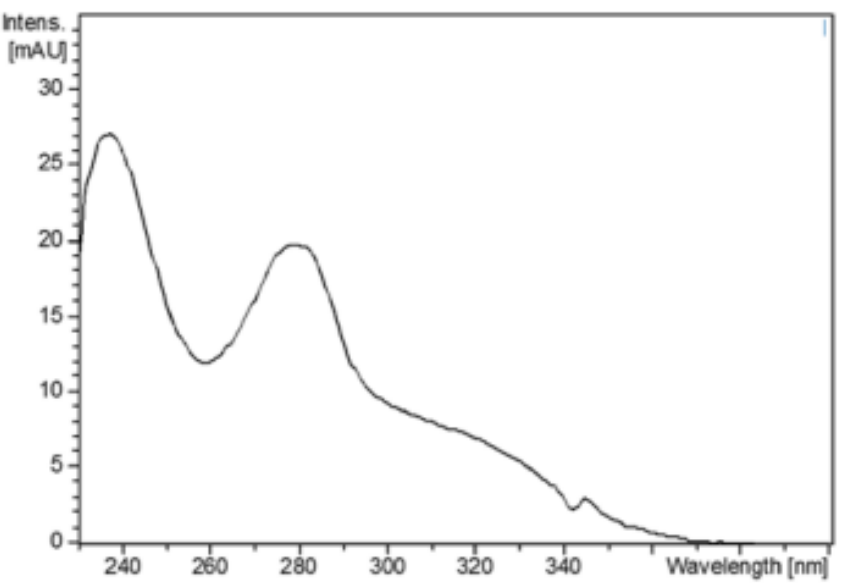

Fig 4 MS/MS and UV absomtion spectra of verbascoside - CA identified in alperujo (compound 11) 
Table 4 UHPLC-DAD quantification of major phenolic compounds in alperujo juice (on fresh basis)

\begin{tabular}{lcc}
\hline Phenolic compound & Content $(\mathrm{mg} / \mathrm{L})$ & Content $(\mathrm{mM})$ \\
\hline Hydroxytyrosol & $370.7 \pm 5.1$ & $2.40 \pm 0.03$ \\
Hydroxytyrosol ghcoside 1 & $165.2 \pm 1.2$ & $1.07 \pm 0.01$ \\
Hydroxytyrosol ghcoside 2 & $88.3 \pm 1.3$ & $0.57 \pm 0.01$ \\
Tyrosol & $148.4 \pm 1.0$ & $1.08 \pm 0.01$ \\
Caffeic acid & $68.0 \pm 1.0$ & $0.38 \pm 0.01$ \\
p-Coumaric acid & $17.7 \pm 0.5$ & $0.11 \pm 0.01$ \\
\hline
\end{tabular}

Expressed as hydroxytyrosol equivalent. Values are mean \pm standard deviation from triplicate analyses

$(\mathrm{m} / \mathrm{z}=623)$ (Cardinali et al. 2012). The ion fragments produced at 459 and 367 correspond to a loss of water and catechol respectively. Peak $11(\mathrm{~m} / \mathrm{z}=461)$ may be identified as the verbascoside derivative formed after hydrolysis of the caffeic acid residue. According to literature, it has never been found in olive pomace but among others in ash (gender: Fraxinus) (Fig. 4) (Sanz et al. 2012). Its fragments at $m / z=315$ and 297 correspond to the successive losses of $\mathrm{Rha}$ and $\mathrm{H}_{2} \mathrm{O}$.

\section{Phenolic Alcohols and Derivatives}

In alperujo juice, phenolic alcohols are the main compounds, such as hydroxytyrosol (peak 5 ) at $\mathrm{m} / \mathrm{z}=153$ and its glucosides (peaks 6 and 7) at $m / z=315$. HT glucosides are commonly identified in olive mill wastes (Leouifoudi et al. 2014; Suárez et al. 2009) but are generally eluted before HT (ElAbbassi et al. 2012; Obied et al. 2005). However, sometimes, the elution order can be reversed (Aranda et al. 2007; Bouaziz et al. 2010; Kanakis et al. 2013; Savarese et al. 2007). This phenomenon may be due to differences in chromatographic phase, particle shape, and particle porosity among the different studies. Peak 12 was identified as tyrosol by standard injection, which was confirmed by its molecular ion at $m / z=137$. Hydroxytyrosol generated the most intense UV

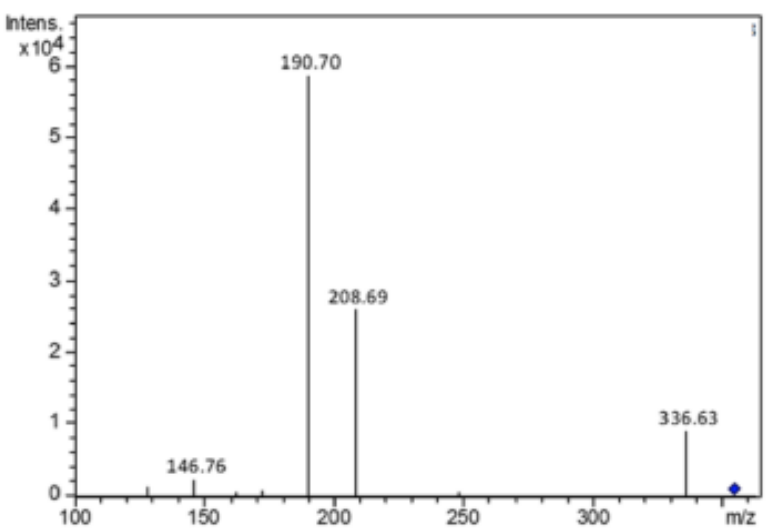

signal. The high concentrations of tyrosol, hydroxytyrosol, and its glucosides confirm the interest of alperujo juice for applications in the food and cosmetic industries (Table 4) (Kalogerakis et al. 2013; Obied et al. 2005).

\section{Phenolic Acids and Derivatives}

Peak 4 at $m / z=329$ is consistent with a vanillic acid hexoside in agreement with its UV spectrum with absorption maxima at 254 and $285 \mathrm{~nm}$ and its fragment at $m / z=167$ (vanillic acid). Additional fragment ions result from demethylation (-14 Da) and decarboxylation (- $44 \mathrm{Da})$, which is characteristic of vanillic acid fragmentation.

Caffeic acid (peak 16) and p-coumaric acid (peak 19) were two of the main phenolic acids identified in alperujo (Obied et al. 2007b). Some of their hexosides (peaks 14 and 17) were also detected with their typical fragment ions featuring hexose loss and subsequent decarboxylation. The presence of chlorogenic acid (peak 15) and ferulic acid (peak 22) was confirmed by injection of intemal standards.

A ferulic acid hexoside (peak 13) was detected as its formic acid ester at $m / z=401$ (an artifact due to the use of $\mathrm{HCO}_{2} \mathrm{H}$ for elution) and its typical fragment ions at $m / z=355$ and 193 featuring the successive losses of formic acid and hexose. Another $p$-coumaric acid derivative was detected at $m / z=355$ (peak 8) with its typical UV spectrum and MS fragments at $m / z=337$ (loss of water), 209, and 191 (loss of p-coumaric acid with or without water addition) (Fig. 5).

A compound with the same characteristics was already found in pineapple and assigned to $p$-coumaroyl aldarate (Steingass et al. 2015). In this work, it is evidenced for the first time in olive. Peak $30(m / z=551)$, which displays major fragments at $m / z=507\left(-\mathrm{CO}_{2}\right), 389$ (loss of a hexose unit), and 179 (caffeic acid) unit, was identified to caffeoyl-6'secologanoside. Finally, peak 32 was identified as comselogoside, the analog of peak 30 with a p-coumaric acid unit (Rubio-Senent et al. 2013).

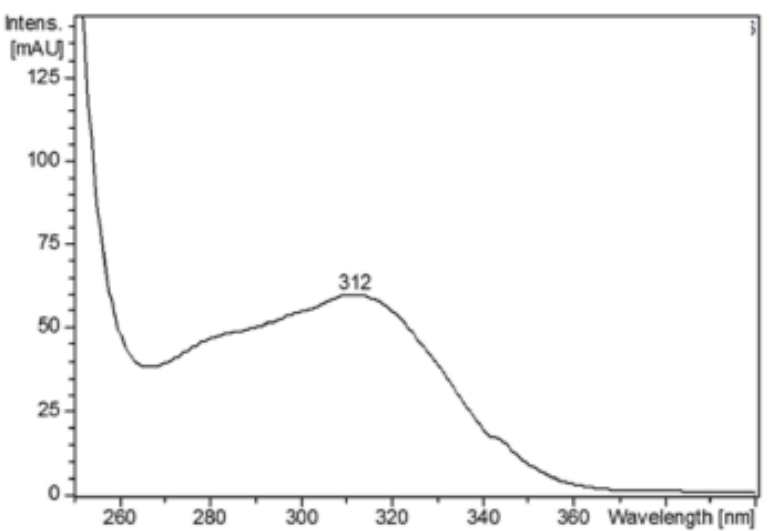

Fig. $5 \mathrm{MS} / \mathrm{MS}$ and UV absorption spectra of $p$-coumaroyl aldarate identified in alperujo (compound 8)
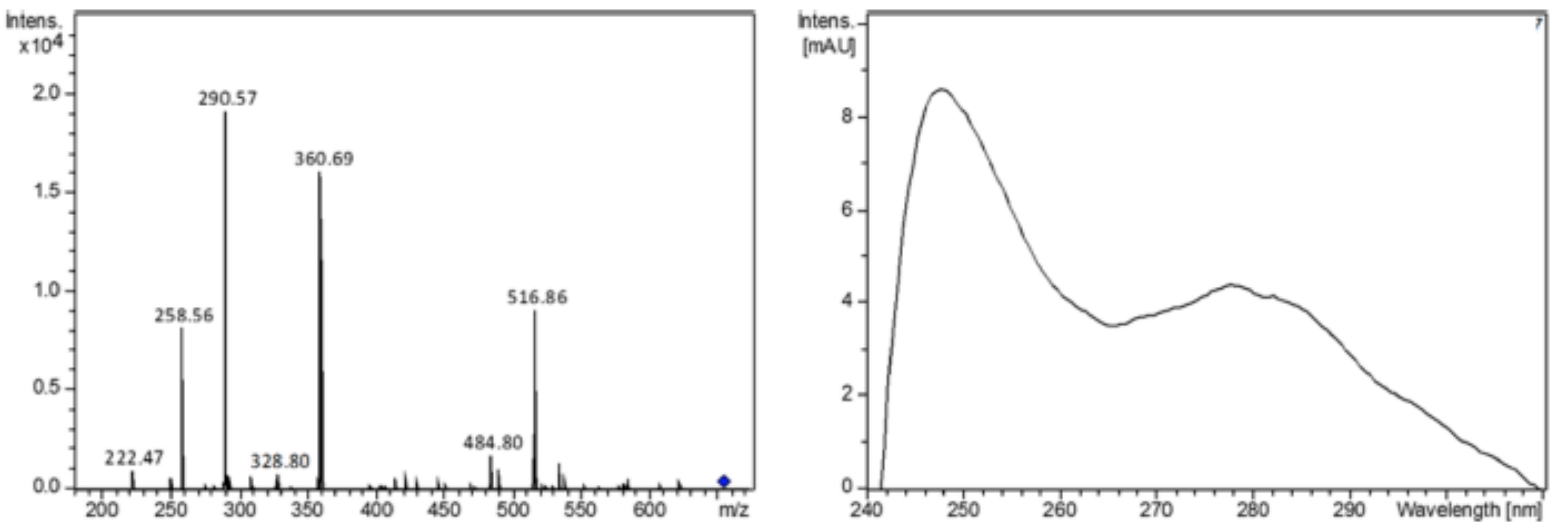

Fig. $6 \mathrm{MS} / \mathrm{MS}$ and UV absorption spectra of ligstroside derivative identified in alperujo (compound 34) 


\section{Flavonoids}

With their major fragment at $m / z=285$ and their UV absorption maxima at 245 and $345 \mathrm{~nm}$, peaks 23 and $24(\mathrm{~m} / \mathrm{z}=593)$ were identified as luteolin derivatives. The loss of $308 \mathrm{Da}$ corresponds to the cleavage of a rutinosyl moiety. Thus, both peaks are proposed to be luteolin- $O$-rutinoside isomers (Leouifoudi et al. 2014).

\section{Iridoids and Derivatives}

Iridoids are monoterpenes characterized by a cyclopentane ring. Ring opening leads to the secoiridoid class. Peaks 3, 9 , $10,18,20,21,25,27,28,29,31,33,34$, and 35 were identified as iridoid and secoiridoid derivatives. For instance, peak $3(\mathrm{~m} / z=537)$ is loganic acid glucoside. Its fragments at $\mathrm{m} / z=375$ and 331 feature hexose loss and subsequent decarboxylation. Peak $25(\mathrm{~m} / \mathrm{z}=241)$ was identified as elenolic acid in agreement with the literature (Lozano-Sánchez et al. 2014). Peak $9(m / z=407$, fragments at $m / z=389,375,357,313$, and 161 ) was previously described by several authors (Cardoso et al. 2005; D'Antuono et al. 2014) and recently identified as 1- $\beta$-glucopyranosyl acyclodihydroelenolic acid (RubioSenent et al. 2015). Peak 10 displays a molecular ion at $m / z=199$ and fragment ions at $m / z=181$ and 155 that are typical of water loss and decarboxylation. It may be ascribed to a hydroxylated derivative of decarboxymethyl elenolic acid. Peak 18 could be assigned to oleoside with its molecular ion at $m / z=389$ and fragment ions at $m / z=345,209$, and 165 , respectively, due to decarboxylation, glucose elimination, and the combination of both. An oleoside deoxyriboside $(m / z=505$, peak 20) was also detected (Peralbo-Molina et al. 2012). Peak 21 was identified as the oleuropein aglycone $(m / z=377$, fragment ions at $m / z=197$ and 153 generated by glucose elimination and additional decarboxylation) (Cardoso et al. 2005; D'Antuono et al. 2014; Rubio-Senent et al. 2013). Tetrahydro-oleuropein (peak 27) was detected with its molecular ion at $m / z=543$ and its fragment at $m / z=525$ (water loss). Peak 28 was ascribed to nüzhenide, an ester of elenolic acid glucoside and tyrosol glucoside commonly found in olive seeds. Its molecular peak $(\mathrm{m} / \mathrm{z}=731)$ actually corresponds to the formate ester with fragments at $m / z=685$ (nüzhenide), 523 (loss of glucose), and 299 (tyrosol glucoside after loss of elenolic acid glucoside) (Silva et al. 2006, 2010). The identification of peak $29(\mathrm{~m} / \mathrm{z}=701)$ as oleuropein glucoside was consistent with the literature (Cardoso et al. 2005; Herrero et al. 2011). The hydroxydecarboxymethyl oleuropein aglycone (peak 31) was also identified by comparison of its UV and mass spectra with literature data (Lozano-Sánchez et al. 2014; Suárez et al. 2008). Peak $34(m / z=655)$ and peak $35(m / z=523)$ were also detected at the end of the elution. Peak 34 may be a ligstroside derivative as the molecular ion at $m / z=655$ generated fragments at $m / z=517$ (loss of tyrosol), 361 (ligstroside after loss of glucose), 291 (ligstroside after loss of glucose and a $\mathrm{C}_{3} \mathrm{H}_{2} \mathrm{O}_{2}$ moiety), and 259 (ligstroside after loss of $\mathrm{C}_{3} \mathrm{H}_{2} \mathrm{O}_{2}$ and $\mathrm{CH}_{3} \mathrm{OH}$ moieties) (Fig. 6). According to our knowledge, this potential ligstroside derivative has never been identified in alperujo juice. Peak 35 displays a molecular peak consistent with ligstroside although its fragments at $m / z=453,421$, and 299 rather suggest that it is an isomer (Cardoso et al. 2011). Finally, peak $33(m / z=539)$ was identified as oleuroside, an oleuropein isomer, with a fragment ion at $\mathrm{m} / \mathrm{z}=377$ consistent with a hexose loss (Cardoso et al. 2011; Kanakis et al. 2013).

\section{Conclusion}

Alperujo juice was analyzed by UHPLC-DAD-MS/MS after a direct injection to preserve the maximal integrity of phenolic compounds and other olive metabolites. Despite the great structural diversity and complexity of alperujo juice, 35 olive metabolites have been separated and identified in only $12 \mathrm{~min}$, including a newly discovered compound (probably a ligstroside

derivative) and two compounds so far not reported in olive ( $p$ coumaroyl aldarate and a verbascoside derivative). This analytical method confirms the high content of hydroxytyrosol and its glucosides in alperujo juice with a total concentration estimated at about $4 \mathrm{mM}$. This method is simple, fast, and effective and can thus be routinely applied in the lab and in the industry to the metabolic profiling of olive juice for the selection of samples according to their biophenol content. 
Acknowledgements This work was supported by the SFR TERSYS, University of Avignon. We thank Mr. Jean-Benoit Hugues and his team (Moulin Castelas, Baux-de-Provence, France) for providing us the twophase olive pomace.

Funding Information This study was funded by the SFR TERSYS, University of Avignon.

\section{Compliance with Ethical Standards}

Conflict of Interest Aurelia Malapert declares that she has no conflict of interest. Emmanuelle Reboul declares that she has no conflict of interest. Michele loonis declares that she has no conflict of interest. Olivier Dangles declares that he has no conflict of interest. Valérie Tomao declares that she has no conflict of interest.

Ethical Approval This article does not contain any studies with human participants or animals performed by any of the authors.

Informed Consent Not applicable.

\section{References}

Alburquerque JA, Gonzálvez J, García D, Cegarra J (2006) Measuring detoxification and maturity in compost made from "alperujo", the solid by-product of extracting olive oil by the two-phase centrifugation system. Chemosphere 64:470-477

Aranda E, Garcia-Romera I, Ocampo JA, Carbone V, Mari A, Malorni A, Sannino F, De Martino A, Capasso R (2007) Chemical characterization and effects on Lepidium sativum of the native and bioremediated components of dry olive mill residue. Chemosphere 69:229-239

Bouaziz M, Jemai H, Khabou W, Sayadi S (2010) Oil content, phenolic profiling and antioxidant potential of Tunisian olive drupes. J Sci Food Agric 90:1750-1758

Cardinali A, Pati S, Minervini F, D'Antuono I, Linsalata V, Lattanzio V (2012) Verbascoside, isoverbascoside, and their derivatives recovered from olive mill wastewater as possible food antioxidants. J Agric Food Chem 60:1822-1829

Cardoso SM, Guyot S, Marnet N, Lopes-da-Silva JA, Renard CM, Coimbra MA (2005) Characterisation of phenolic extracts from olive pulp and olive pomace by electrospray mass spectrometry. J Sci Food Agric 85:21-32

Cardoso SM, Falcão SI, Peres AM, Domingues MRM (2011) Oleuropein/ligstroside isomers and their derivatives in Portuguese olive mill wastewaters. Food Chem 129:291-296

Conseil Oléicole International (2013) ECONOMIE: 1,5 milliards d'oliviers dans le monde - Olive Info

D'Antuono I, Kontogianni VG, Kotsiou K, Linsalata V, Logrieco AF, Tasioula-Margari M, Cardinali A (2014) Polyphenolic 
characterization of olive mill wastewaters, coming from Italian and Greek olive cultivars, after membrane technology. Food Res Int 65:301-310

Dermeche S, Nadour M, Larroche C, Moulti-Mati F, Michaud P (2013) Olive mill wastes: biochemical characterizations and valorization strategies. Process Biochem 48:1532-1552

El-Abbassi A, Kiai H, Hafidi A (2012) Phenolic profile and antioxidant activities of olive mill wastewater. Food Chem 132:406-412

Giordano E, Dangles O, Rakotomanomana N, Baracchini S, Visioli F (2015) 3-O-Hydroxytyrosol glucuronide and 4-Ohydroxytyrosol glucuronide reduce endoplasmic reticulum stress in vitro. Food Funct 6:3275-3281

Herrero M, Temirzoda TN, Segura-Carretero A, Quirantes R, Plaza M, Ibañez E (2011) New possibilities for the valorization of olive oil by-products. J Chromatogr A 1218:7511-7520

Kalogerakis N, Politi M, Foteinis S, Chatzisymeon E, Mantzavinos D (2013) Recovery of antioxidants from olive mill wastewaters: a viable solution that promotes their overall sustainable management. J Environ Manag 128:749-758

Kanakis P, Termentzi A, Michel T, Gikas E, Halabalaki M, Skaltsounis A-L (2013) From olive drupes to olive oil. An HPLC-Orbitrap-based qualitative and quantitative exploration of olive key metabolites. Planta Med 79:1576-1587

Kapellakis IE, Tsagarakis KP, Crowther JC (2008) Olive oil history, production and by-product management. Rev Environ Sci Biotechnol 7:1-26

Leouifoudi I, Zyad A, Amechrouq A, Oukerrou MA, Mouse HA, Mbarki M (2014) Identification and characterisation of phenolic compounds extracted from Moroccan olive mill wastewater. Food Sci Technol Camp 34:249-257

Lozano-Sánchez J, Castro-Puyana M, Mendiola J, Segura-Carretero A, Cifuentes A, Ibáez E (2014) Recovering bioactive compounds from olive oil filter cake by advanced extraction techniques. Int J Mol Sci 15:16270-16283

Niaounakis M, Halvadakis CP (2006) Olive processing waste management literature review and patent survey. Elsevier, Amsterdam; London

Obied HK, Allen MS, Bedgood DR, Prenzler PD, Robards K (2005) Investigation of Australian olive mill waste for recovery of biophenols. J Agric Food Chem 53:9911-9920

Obied HK, Bedgood DR, Prenzler PD, Robards K (2007a) Bioscreening of Australian olive mill waste extracts: biophenol content, antioxidant, antimicrobial and molluscicidal activities. Food Chem Toxicol 45:1238-1248

Obied HK, Bedgood DR, Prenzler PD, Robards K (2007b) Chemical screening of olive biophenol extracts by hyphenated liquid chromatography. Anal Chim Acta 603:176-189

Ollivier D, Pinatel C, Ollivier V, Artaud J (2014) Composition en acides gras et en triglycérides d'huiles d'olive vierges de 34 variétés et 8 Appellations d'Origine Françaises et de 2 variétés étrangères implantées en France: Constitution d'une banque de données (lère partie). Olivae 36-48

Peralbo-Molina Á, Priego-Capote F, Luque de Castro MD (2012) Tentative identification of phenolic compounds in olive pomace extracts using liquid chromatography-tandem mass spectrometry with a quadrupole-quadrupole-time-of-flight mass detector. J Agric Food Chem 60:11542-11550

Priego-Capote F, Ruiz-Jiménez J, Luque de Castro M (2004) Fast separation and determination of phenolic compounds by capillary electrophoresis-diode array detection. J Chromatogr A 1045:239-246

Rubio-Senent F, Rodriguez-Gutierrez G, Lama-Muñoz A, Fernández-Bolaños J (2012) New phenolic compounds 
hydrothermally extracted from the olive oil byproduct alperujo and their antioxidative activities. J Agric Food Chem 60:11751186

Rubio-Senent F, Rodriguez-Gutiérrez G, Lama-Muñoz A, Fernández-Bolanios J (2013) Phenolic extract obtained from steam-treated olive oil waste: characterization and antioxidant activity. LWT-Food Sci Technol 54:114-124

Rubio-Senent F, Martos S, Lama-Muñoz A, Fernández-Bolaños JG, Rodríguez-Gutiérrez G, Fernández-Bolaños J (2015) Isolation and identification of minor secoiridoids and phenolic components from thermally treated olive oil by-products. Food Chem 187:166-173

Sanz M, Simón BF, Cadahía E, Esteruelas E, Mữoz AM, Hemández T, Estrella I, Pinto E (2012) LC-DAD/ESI-MS/MS study of phenolic compounds in ash (Fraxinus excelsior L. and F. americana L.) heartwood. Effect of toasting intensity at cooperage: LC-DAD/ESI-MS/ MS of ash wood phenolic compounds. J Mass Spectrom 47:905-918

Savarese M, Demarco E, Sacchi R (2007) Characterization of phenolic extracts from olives (Olea europaea cv. Pisciottana) by electrospray ionization mass spectrometry. Food Chem 105 : 761-770

Silva S, Gomes L, Leitao F, Coelho AV, Boas LV (2006) Phenolic compounds and antioxidant activity of Olea europaea L. fruits and leaves. Food Sci Technol Int 12:385-395

Silva S, Gomes L, Leitão F, Bronze M, Coelho AV, Boas LV (2010) Secoiridoids in olive seed: characterization of nūzhenide and 11-methyl oleosides by liquid chromatography with diode array and mass spectrometry. Grasas Aceites 61:157-164

Steingass CB, Glock MP, Schweiggert RM, Carle R (2015) Studies into the phenolic patterns of different tissues of pineapple (Ananas comosus [L.] Merr.) infructescence by HPLC-DAD-ESI-MS $\mathrm{n}$ and GC-MS analysis. Anal Bioanal Chem 407:6463-6479

Suárez M, Macià A, Romero M-P, Motilva M-J (2008) Improved liquid chromatography tandem mass spectrometry method for the determination of phenolic compounds in virgin olive oil. J Chromatogr A 1214:90-99

Suárez M, Romero M-P, Ramo T, Macià A, Motilva M-J (2009) Methods for preparing phenolic extracts from olive cake for potential application as food antioxidants. J Agric Food Chem 57:1463-1472

Visioli F, Bernardini E (2011) Extra virgin olive oil's polyphenols: biological activities. Curr Pharm Des 17:786-804 